\title{
GEOTHERMAL RESERVOIR CHARACTERIZATION FOR STEAM FIELD MANAGEMENT IN KAMOJANG GEOTHERMAL FIELD-WEST JAVA
}

\author{
Z. Abidin $^{1 *}$, R. Prasetio ${ }^{1}$ and Prayoto ${ }^{2}$ \\ ${ }^{1}$ Center for Application of Isotopes and Radiation Technology, \\ National Nuclear Energy Agency (BATAN) \\ J1 Lebak Bulus Raya No.49,Jakarta 12770 \\ ${ }^{2}$ Gadjah Mada University, Yogyakarta \\ Received 15 January 2009; Received in revised form 1 May 2009; Accepted 5 May 2009
}

\begin{abstract}
GEOTHERMAL RESERVOIR CHARACTERIZATION FOR STEAM FIELD MANAGEMENT IN KAMOJANG GEOTHERMAL FIELD-WEST JAVA. Kamojang is the first geothermal field in Indonesia with a vapor dominated system reservoir. Kamojang has been exploited for over 20 years producing about 1100 tons/hour of steam which is equivalent to 140 Mwe electricity energy. This research is aimed to study the reservoir character after 20 years of exploitation and to investigate the effect of reinjection as a artificial recharge for steam input in the future and also the nature of secondary processes in the reservoir using isotope geochemistry tools.

The research is conducted by natural isotopes $\left({ }^{18} \mathrm{O},{ }^{2} \mathrm{H}\right.$ and $\left.{ }^{3} \mathrm{H}\right)$ analysis of many sources of water (meteoric, cold spring, fumaroles and shallow groundwater) in the surrounding of Kamojang field and also fluid reservoir to establish fluid reservoir origins and isotopic composition. Gas analysis and isotopes monitoring on the 25 production wells have been conducted every 2-3 years intervals for more than 10 years to investigate the effect of exploitation to the reservoir performance. Tritium radiotracer test with $370 \mathrm{GBq}(10 \mathrm{Ci})$ activity was conducted at the KMJ 15 reinjection well to determine qualitatively and quantitatively the flow of reinjection water to its surrounding producing well (KMJ 11, 14, 17, 18, 26, 17 and 30). Data interpretation and evaluation to determine reinjection water mass recovery and cooling prediction modeling were conducted using ICEBOX program package (TRINV and TRCOOL).

Interpretation and evaluation of data concluded that reservoir fluid of Kamojang geothermal field was originated from meteoric water which infiltrated through fault structures at elevation of $1350 \mathrm{~m}-1650 \mathrm{~m}$ above sea level. There is no evidence that the fluid was originated from magmatic water. Reservoir fluid moved both laterally and vertically (deep fluid) with lateral fluid movement from west to the east. The isotope data analysis indicated there is water entry in west-northwest reservoir boundary. Water entry gradually moved from northwest to the southeast (through wells of KMJ 42, 40, 27, 26 and 28). Exploitation effect to ten of the observation wells shows a decrease in $\mathrm{w} / \mathrm{r}$ ratio and liquid saturation from $35 \%$ in the beginning to about $20,5 \%$ on the average after 20 years of operation. Evaluation with TRINV and TRCOOL program shows that $13,5 \%$ of water reinjected into KMJ 15 reinjection well was recovered in the surrounding production wells. The program model of the reservoir temperature cooling shows that water reinjection with flow rate of $10 \mathrm{~kg} / \mathrm{sec}$ is very save. After 20 years of reinjection activity, the model predicts a production wells will be cooling of about $6.8^{\circ} \mathrm{C}$.
\end{abstract}

Keywords : Reservoir, TRINVI, TRCOOL, Isotope and vapor dominated, Kamojang, Natural isotopes.

(ㄷ) 2009 Atom Indonesia. All rights reserved.

\footnotetext{
* Corresponding author.

E-mail addresses: abidin@batan.go.id (Z. Abidin)
} 


\section{INTRODUCTION}

Geothermal reservoir characterization has an important role to support steam production. Reservoir characteristics are closely related to the reservoir potential in term of fluid origin, temperature, pressure, water content and fluid movement which must be clearly understood in the exploitation and monitoring a geothermal field. A change in the reservoir characteristic during the operational production must be monitored continuously in order to detect possible production decline or changes in the reservoir performance.

Characterization of the Kamojang vapor dominated reservoir has been undertaken by isotope geochemistry method making use of the natural isotopes $\left({ }^{18} \mathrm{O},{ }^{2} \mathrm{H},{ }^{3} \mathrm{H}\right)$ and gases $\left(\mathrm{CO}_{2}, \mathrm{H}_{2}, \mathrm{H}_{2} \mathrm{~S}\right.$ and $\left.\mathrm{CH}_{4}\right)$. Tritium radiotracer test was undertaken on the KMJ 15 reinjection well to determine well interconnection, mass recovery and the related influence on the reservoir performance, primarily the reservoir cooling. As a reference, the Kamojang field has been subjected to various detailed investigations covering exploration, geology, geophysics and geochemistry and also some of the reservoir potential investigation undertaken by local and foreign consultants [1](Satyajit, et al, 1999). Those works have provided a considerable database that can be integrated with the present work in a comprehensive study to be aimed on formulation of steam field management for the future.

Kamojang field is a valuable national asset because of its operational advantages, ease in handling and relatively cheap steam price. After 20 years of steam production, Kamojang indicates a decline in production of around 3-4 \% per year. Characterization of the reservoir is expected to give some input for the formulation of steam field management strategy in order to maintain steam production for more than 30 years.

So, reservoir characterization of the Kamojang geothermal field after 20 years of production is necessary for the evaluation of production rate, temperature, water saturation data and change or processes occurring in the reservoir as affected by the exploitation. Recently, it has been established that the reservoir is undergoing a decline in production of about 3-4\% per year. In addition, the reservoir temperature in various wells is also decreasing. Monitoring data of natural isotopes $\left({ }^{18} \mathrm{O}\right.$ and $\left.{ }^{2} \mathrm{H}\right)$ and gases and radiotracer tests is the best method to study reservoir changes during exploitation at vapor dominated system. The results will be formulated as long term steam field management strategy.

The aims of this research are: (a) to study the relationship between the meteoric water ${ }^{18} \mathrm{O}$ and ${ }^{2} \mathrm{H}$ isotope composition in the fluids reservoir, degree of ${ }^{18} \mathrm{O}$ exchange in water rock interaction and the movement and the physical changes of steam during its movement in the reservoir, (b) to determine the steam fraction, temperature and water saturation in reservoir as related to the geochemical processes in the reservoir in order to study the steam quality and reservoir production, (c) to study the effect of reinjection well to the surrounding production wells using tritium radiotracers tests. 
Time breakthrough, mass recovery and cooling prediction in the reservoir will be evaluated by TRINV and TRCOOL programs.

\section{Regional geology of Kamojang field}

Kamojang geothermal field is located in a big volcanic chain between Rakutak Mountain in the west and Guntur Mountain in the east that is $15 \mathrm{~km}$ long and $4.5 \mathrm{~km}$ wide. The chain is a volcanic complex ranging from the oldest in the west to the youngest in the east namely: Rakutak Mountain, Ciharus Lake, Pangkalan Lake, Gandapura Mountain, Masigit Mountain and Guntur Mountain (Robert, 1988). Rakutak-Guntur volcanic chain is influenced by a big graben with southwest-notheast direction that is $6 \mathrm{~km}$ wide from Ciharus Lake to the Kamojang crater.

\section{Isotope Geohemistry}

Celaty et al, (1991) and Gunderson, (1991) separately have undertaken ${ }^{18} \mathrm{O}$ and ${ }^{2} \mathrm{H}$ isotopes distribution investigation for vapor dominated systems in Larderello-Italy and Geyser-USA. The isotope distribution was used to describe movement and origin of the fluids and also various processes occurring in the reservoir such as water entry (recharge), water-rock interaction and condensation-evaporation processes. Those processes are related to the rate of steam production and reservoir performance changes due to exploitation.

D'Amore and Truesdell (1995) have undertaken monitoring investigation to observe steam flow, gas/steam ratio and ${ }^{18} \mathrm{O}$. The results combined with physics parameter calculation using Grid method was used to evaluate the influence of exploitation on the artificial and natural recharge and also on steam migration. The interpretation of results gave significant insight to steam field management problems.

Reinjection in a geothermal system is an essential part of any modern, sustainable, environmentally friendly geothermal utilization and is an important part of the management of geothermal resources. Reinjection could increase steam production, although it should be done precisely with respect to amount of water and the choice of well reinjection location (Axelsson, 2002). More than 50 geothermal fields in the world applied tracer technique and radiotracer technique as one of the dominant methods. Tracer technique is used as a tool for interpretation and evaluation of water reinjection influence to the reservoir. Program package ICEBOX (TRINV and TRCOOL) developed by Axelsson, 2002 could be used for mass recovery calculation and cooling reservoir prediction. 


\section{MATERIALS AND METHOD}

\section{Sampling of reservoir fluids and surface water}

The sampling of steam fluid, spring water and surface water for analysis of environmental isotope, tritium and gases was done at Kamojang field and its vicinity. The reservoir fluid was taken using total condensate method by condenser instrument. The gas was sampled using specific bottle filled with $100 \mathrm{~mL} \mathrm{NaOH} 6 \mathrm{~N}$ liquid.

\section{Sampling of meteoric water}

Sampling of meteoric water was done using four rain station at $700 \mathrm{~m}$, $1000 \mathrm{~m}, 1485 \mathrm{~m}$ and $1650 \mathrm{~m}$ above sea level. Sampling was conducted montly during rainy season

\section{Injection of tritium tracer}

Injection of tritium tracer with activity of $370 \mathrm{GBq}$ was conducted at the head of the reinjection well KMJ 15. The pressure of KMJ 15 well was negative $\left(-1 \mathrm{~kg} / \mathrm{cm}^{2}\right)$ and the process was in normal condition.

\section{Analysis of ${ }^{18} \mathrm{O}$ and ${ }^{2} \mathrm{H}$ isotopes}

${ }^{18} \mathrm{O}$ isotope was analyzed by means of isoprep-18 using Epstein Mayeda method and ${ }^{2} \mathrm{H}$ isotope was analyzed by reaction of the water sample with active $\mathrm{Zn}$ in special bottle at vacuum condition and heated at $450{ }^{\circ} \mathrm{C}$ for 45 minutes. Both of ${ }^{18} \mathrm{O}$ and ${ }^{2} \mathrm{H}$ isotopes were analyzed using mass spectrometer.

\section{Analysis of tritium}

Tritium was analyzed by enrichment process using electrolysis method. The result of the electrolysis was counted using liquid scintillation counter.

\section{Analysis of gases}

Gases were analyzed for $\mathrm{H}_{2}$ and $\mathrm{CH}_{4}$ using gas chromatography (auto GC Perkin Elmer) complemented with Arnell injector and TCD detector, while $\mathrm{CO}_{2}$ and $\mathrm{H}_{2} \mathrm{~S}$ were analyzed by titration method. 


\section{RESULTS AND DISCUSSION}

\section{Isotope Data of Meteoric Water and Recharge Area}

Based on the monitoring of isotope of rain water, the relationship between elevation (E) and isotope content of ${ }^{18} \mathrm{O}$ and ${ }^{2} \mathrm{H}$ of rain water in Kamojang field was obtained as;

$$
\begin{aligned}
& { }^{18} \mathrm{O}=-\left(1.8 \times 10^{-3}\right) \mathrm{E}-5.1978 \\
& { }^{2} \mathrm{H}=-\left(1.45 \times 10^{-2}\right) \mathrm{E}-25.652
\end{aligned}
$$

Equations (1) and (2) determine that the recharge area of Kamojang field ranges from elevations of $1350 \mathrm{~m}$ to $1650 \mathrm{~m}$ above sea level. The linear equation of local meteoric line in Kamojang area (Figure 1) is ;

$$
{ }^{2} \mathrm{H}=8,05{ }^{18} \mathrm{O}+16.48
$$

and the linear equation of the geothermal fluid in Kamojang field is ;

$$
{ }^{2} \mathrm{H}=0,2082{ }^{18} \mathrm{O}+44.81
$$

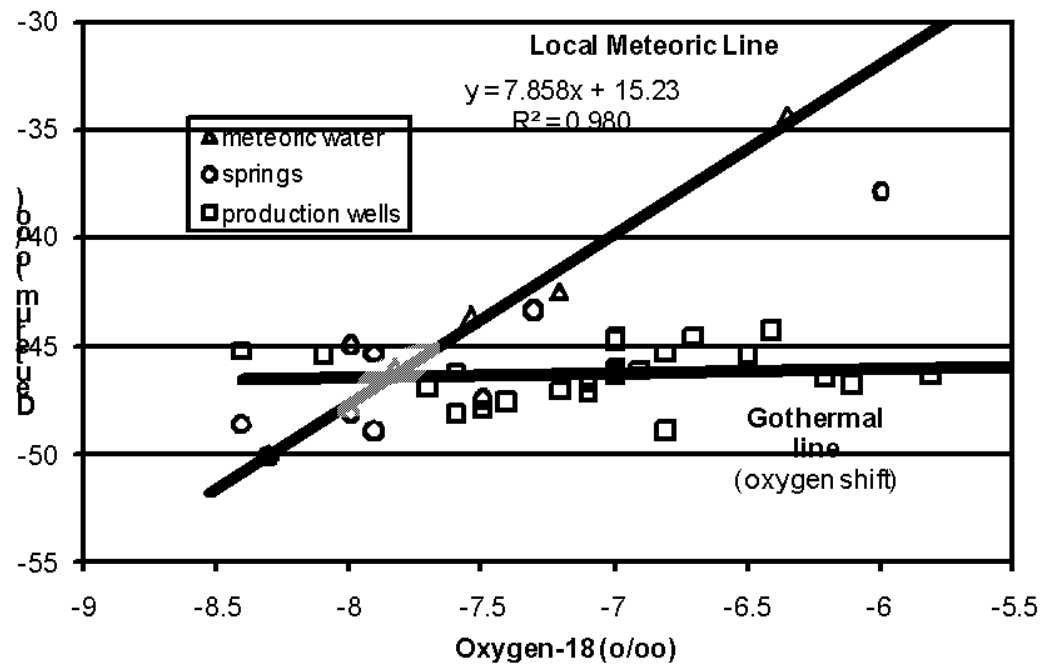

Figure 1. Relationship between ${ }^{18} \mathrm{O}$ and ${ }^{2} \mathrm{H}$ meteoric water, springs and fluid reservoir 


\section{Effect of Exploitation on Reservoir Characteristic}

\section{Monitoring of ${ }^{18} \mathrm{O}$ isotope}

The geographical distribution of isotopic contour pattern in 1989 indicates that there are 3 distribution zones with different isotope value of ${ }^{18} \mathrm{O}$, namely north east-south west zone, north zone and west-north west zone. It is concluded that the area of water entry into reservoir is west-north west boundary (Figure 2).

\section{Water rock interaction}

Changes in ${ }^{18} \mathrm{O}$ isotopic content in production well steam from 1989, 1992 and 1998 (Figure 3) correlate with steam-rock interaction. This correlation provides information on how temperature and water to rock mass ratio (w/r) during 10 years of exploitation were. The significant changes in w/r mass ratio where found from 1992 to 1998. In KMJ 35, 37 and 41, w/r mass ratio decrease, while in KMJ 22 and 28 it increases. However, the increase in $\mathrm{w} / \mathrm{r}$ mass ratio is accompanied by ligan insignificant decrease in reservoir temperature. That is only $11.3{ }^{\circ} \mathrm{C}$. This condition does not influence production. On the other hand, increase of $w / r$ mass ratio has caused relatively high drop in temperature of $24.3{ }^{\circ} \mathrm{C}$ at well KMJ 28. Although there was significant decrease in the production in well KMJ 28, it has to be concerned because condensation process, shown by ${ }^{18} \mathrm{O}$ depletion may cause problem in future. The decrease in w/r mass ratio at KMJ 37 and KMJ 41 has been found significantly high; ranging from 0.8 and 0.6 to lower than 0.4 respectively. In addition to that a decrease in w/r mass ratio at well KMJ 37 has been accompanied by a decrease in temperature of approximately $10^{\circ} \mathrm{C}$, and yet the temperature at KMJ 41 has not changed for 10 years production. 


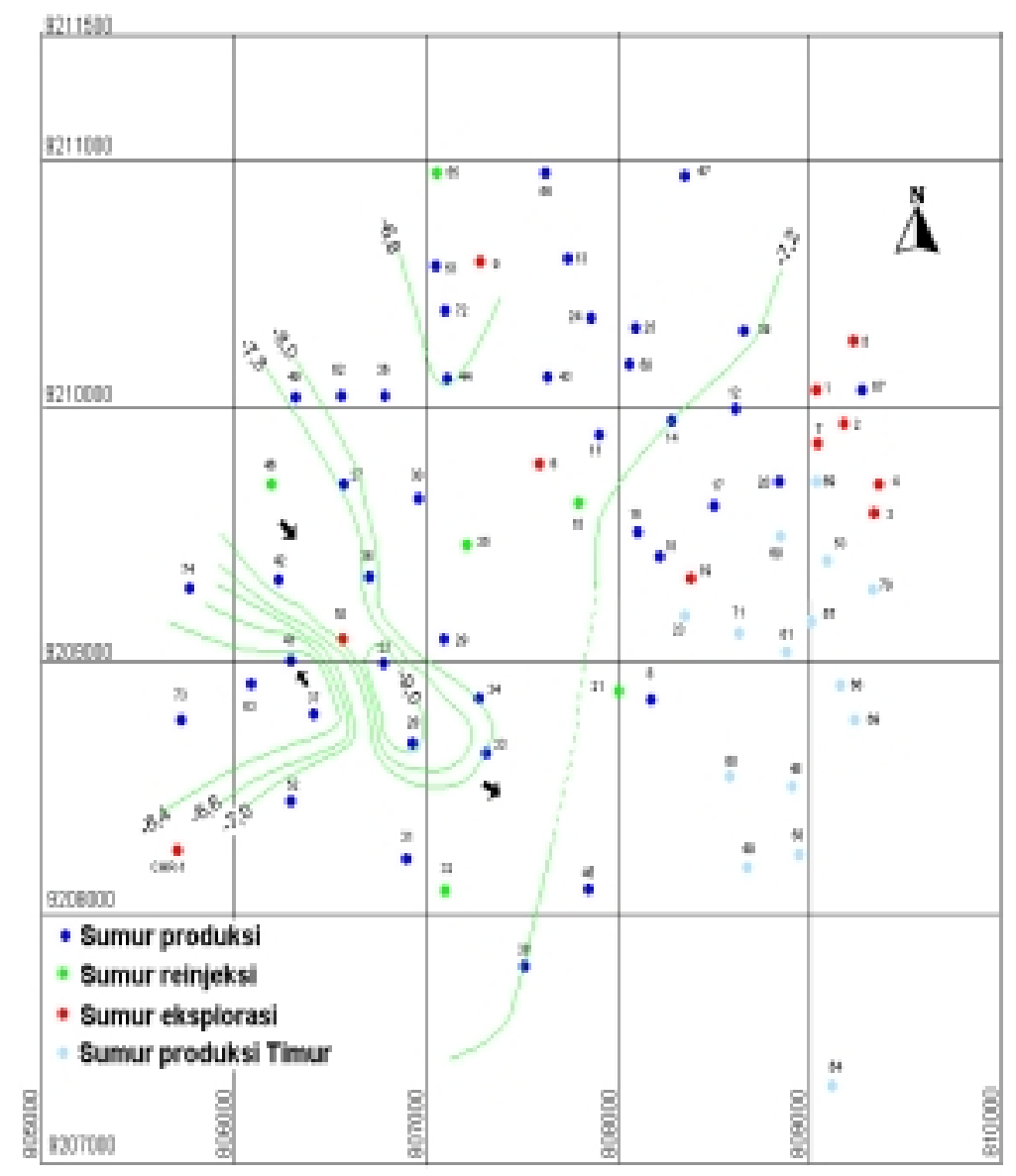

Figure 2. Distribution of ${ }^{18} \mathrm{O}$ reservoir fluids (1998).

Production well in north east, namely KMJ 11, 17 and 18, are very important, continuous high production has been going on for10 years. There is no significant decline in $\mathrm{w} / \mathrm{r}$ mass ratio and temperature. On the other hand, KMJ 14 has shown significant decrease in mass ratio during 10 years of production, even though a temperature decrease of about $16.1^{\circ} \mathrm{C}$ is not significant 


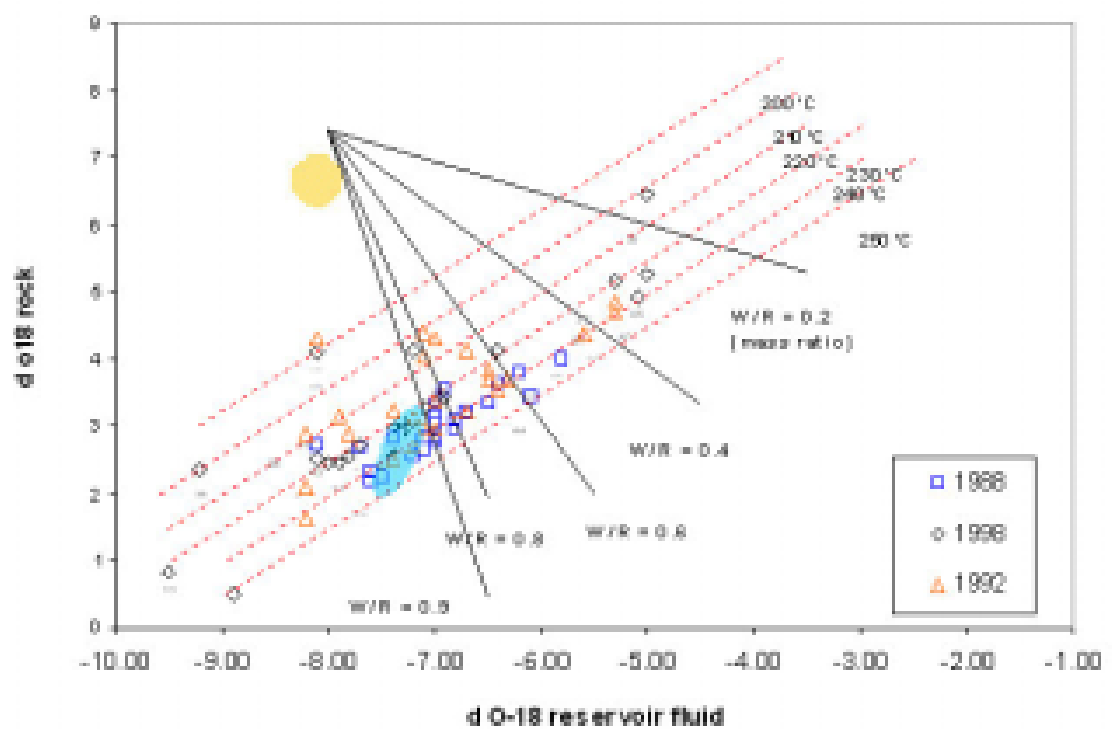

Figure 3. Water-rock interaction processes in reservoir at 1989,1992 and 1998.

\section{Influence of Reinjection Well to the Reservoir}

\section{Tracer technique}

The results of tritium test in 1989 and monitoring in 1992 and 1994 indicate that the concentration of tritium at KMJ 11, 14, 17, 18 and 35 originated from artificial isotopes injected in 1983 at reinjection well KMJ 15. Tritium isotope reinjected in 1992 at KMJ 15 has been detected in 1996 in production wells of western and eastern areas, namely KMJ 11, 14, 17, 18, 35, 26, 27 and 30.

\section{Evaluation of time breakthrough and mass recovery}

The results of TRINV model in the well of eastern part showed that the time breakthrough (t) for well KMJ 11 has the shortest flow path $(838.3 \mathrm{~m})$ and the shortest time i.e, $1.735 \times 10^{8}$ seconds (5.5 years). On the other hand, KMJ 17 has the far flow path and time breakthrough of $2.05 \times 108$ seconds (6.5 years) which represent the longest time breakthrough. KMJ 14 and 18 have relatively similar time breakthrough of $1.892 \times 10^{8}$ seconds (6.0 years), although KMJ 14 has a longer flow path than KMJ 18. This condition is due to the suspected lateral fault in KMJ 14 . The results of mass recovery model show that the KMJ 11, KMJ 14, KMJ 17 and KMJ 18 with respective production rates of $20.0 \mathrm{~kg} / \mathrm{sec}, 13.4 \mathrm{~kg} / \mathrm{sec}, 15.3 \mathrm{~kg} / \mathrm{sec}$ and $28.9 \mathrm{~kg} / \mathrm{sec}$ and 
permeability $30-47 \mathrm{mD}, 6.5 \mathrm{mD}, 30 \mathrm{mD}$ and $120 \mathrm{mD}$ have recovery of $2.2 \%$, $1.25 \%, 0,86 \%$ and $4.04 \%$. Total mass recovery of well in eastern part is $8.35 \%$ which is equivalent to an additional amount of $3.95 \times 10^{5}$ tons. Moreover, the modeling result on the western wells shows that KMJ 26 has a pathway of $1141.4 \mathrm{~m}$, permeability over $24 \mathrm{mD}$ and production rate of $16.3 \mathrm{~kg} / \mathrm{sec}$ with the highest penetration time of $2.21 \times 108$ seconds ( 7.0 years) but it has the highest mass recovery of $2.69 \%$. KMJ 27 with the longest pathway $(1272.4 \mathrm{~m})$, permeability $19.0 \mathrm{mD}$ and the highest rate of production $(19.6 \mathrm{~kg} / \mathrm{sec})$ has the shortest penetration time of $2.05 \times 10^{8}$ seconds (6.5 years) and mass recovery of $2.03 \%$. On the contrary, KMJ 30 which has a shortest pathway $(1023.3 \mathrm{~m})$, lower permeability $(6.4 \mathrm{mD})$ and also lower rate of production $(5.5 \mathrm{Kg} / \mathrm{sec})$ than the others (KMJ 26 and 27) has a penetration time of $2.10 \times 10^{8}$ seconds (6.66 years) and the lowest mass recovery of $0.43 \%$. The total mass recovery in well in the western part is $5.15 \%$. Further, the total mass recovery in the western and the eastern zone are $13.5 \%$, which is equivalent to $6.9 \times 10^{5}$ tons.

\section{Prediction of cooling process and optimalisation of reinjection water}

The result of model simulation for predicting the cooling off process offers significant information on the effect of various flow rates. From the result show that reinjection water flow rate level of $5 \mathrm{~kg} / \mathrm{s}$ for all reinjection wells show no significant decrease in temperature. However at a flow rate level of $10 \mathrm{~kg} / \mathrm{s}$, all reinjection wells show a decrease in reservoir temperature after 20 years. It ranges from $0.48{ }^{\circ} \mathrm{C}$ to $11.68{ }^{\circ} \mathrm{C}$ with an average of $6.82{ }^{\circ} \mathrm{C}$. The lowest temperature decrease is $0.48{ }^{\circ} \mathrm{C}$ at KMJ 30, and the highest is $11.8{ }^{\circ} \mathrm{C}$ at KMJ 27. At a flow rate level of $15 \mathrm{~kg} / \mathrm{s}$ (Figures 4 and 5), the reduction in reservoir temperature after 20 years range from $19.90{ }^{\circ} \mathrm{C}$ to $52.0{ }^{\circ} \mathrm{C}$ with an average of $33.68{ }^{\circ} \mathrm{C}$. Further, at $20 \mathrm{~kg} / \mathrm{s} \mathrm{level,} \mathrm{the} \mathrm{reservoir}$ temperature decreases gradually to about $62.69{ }^{\circ} \mathrm{C}$. The temperature ranges from $31.96^{\circ} \mathrm{C}$ to $104.33^{\circ} \mathrm{C}$. The result of reservoir cooling prediction using TRCOOL program show that reinjection with a flow rate level of $20 \mathrm{~kg} / \mathrm{s}$ at KMJ 15 may hamper the reservoir. The best level of flow rate recommended is $10 \mathrm{~kg} / \mathrm{s}$. At this flow rate the reservoir does not show a significant change in temperature. Even after 20 years of operation the average temperature reduction is only $6.82^{\circ} \mathrm{C}$, which is save for the reservoir. 


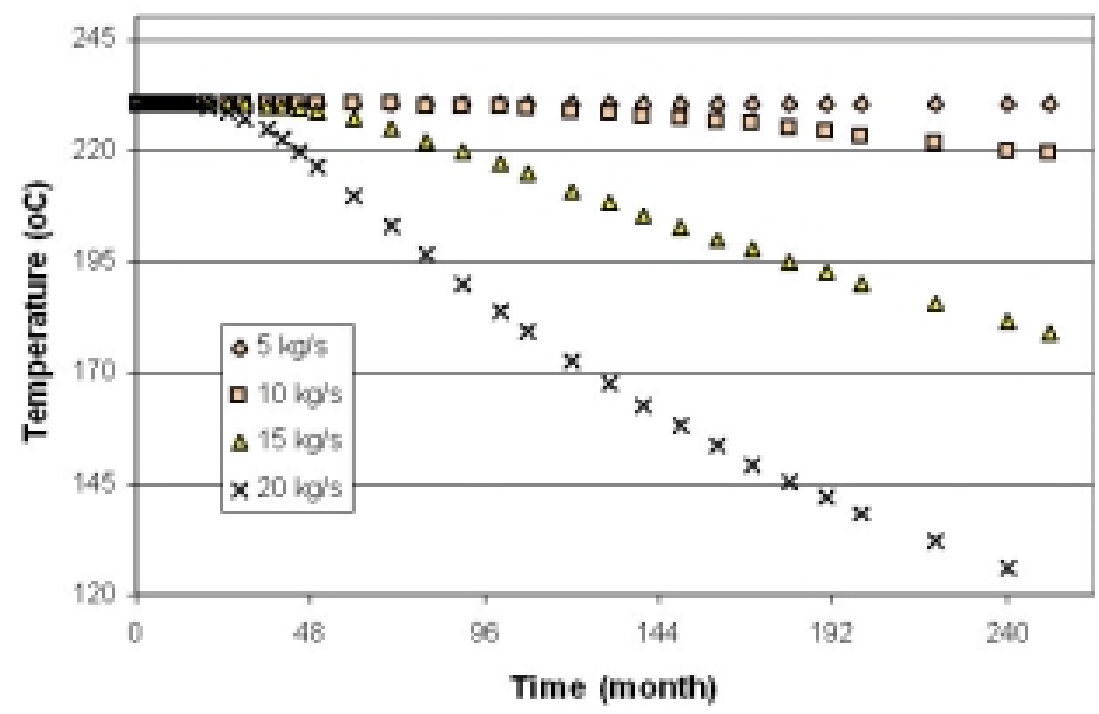

Figure 4. Optimation curve of water reinjection flow rate resevoir cooling prediction for KMJ 14 by TRCOOL program.

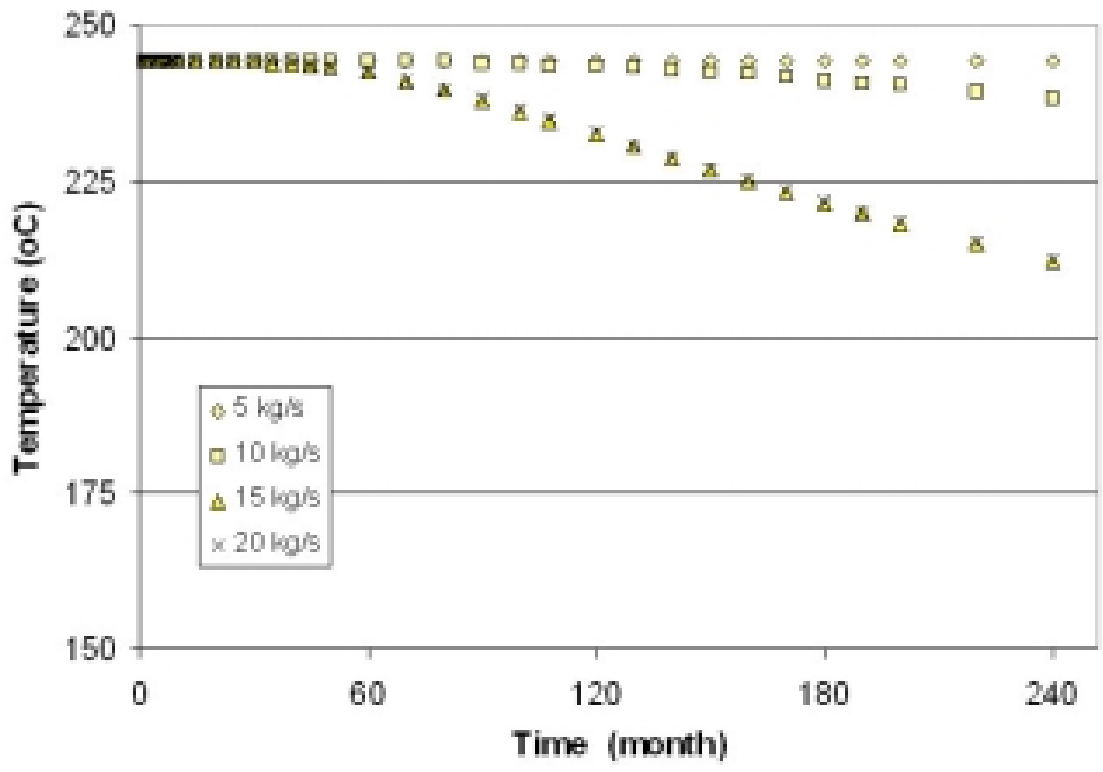

Figure 5. Optimation curve of water reinjection flowrate to the reservoir cooling prediction for KMJ 11 by TRCOOL program. 


\section{Evaluation by Analysis Gas}

The results of gas/steam ratio and ${ }^{18} \mathrm{O}$ isotope monitoring in all fields between 1989 and 2002 show that for wells located in the middle i.e, KMJ 11, 14, 17 and 18, the gas/steam ratio decreases gradually during 13 years period. The decrease in gas/steam ratio results in a decline in reserved water saturation. KMJ 22, shows a high fluctuation of gas/steam ratio in 1998. The ratio was 143.7 in 1992 and decreased to 65.2 in 1998. The difference was probably caused by evaporation condensation process which happened in situ or recharge water flowing from north-west entering the reservoir system. This conclusion was supported by the result of isotope 180 monitoring which was relatively depleted in 1998. In the mean time the gas/steam ratio in the north-western part (KMJ 27) seems to decrease. On the other hand KMJ 44 tend to increase (loss of potensial reserve water), and KMJ 36 seems to be stable.

The result of Grid curve evaluation shows that the average reservoir temperature is $230 \pm 20{ }^{\circ} \mathrm{C}$, while the water saturation from 10 production wells is $20.5 \%$. In 1979, Grant has calculated that the average water saturation at the beginning of Kamojang field exploitation is about $35 \%$. As the result, after 20 years of production, it is estimated that the reservoir has lost about $14.5 \%$ of its liquid saturation.

\section{CONCLUSIONS}

Characterization of the steam dominated Kamojang geothermal field using environmental isotope method $\left({ }^{18} \mathrm{O},{ }^{2} \mathrm{H},{ }^{3} \mathrm{H}\right),{ }^{3} \mathrm{H}$ tracer and gas analysis has led to the following conclusions:

- Data interpretation of ${ }^{18} \mathrm{O}$ and ${ }^{2} \mathrm{H}$ isotopes in rain water at several altitudes in ground water and spring water around Kamojang field, fumaroles and reservoir fluid reveals that the fluid in reservoir has come from recharge area and has not been influenced by magmatic water.

- Kamojang field reservoir may be divided into 3 main zones namely, south-west zone, north-east zone, west-north zone, and north zone and there is recharge water (water entry) to the steam reservoir in the boundary area of reservoir in western-north Zone flow direction of recharge is dominated by fluid movement from north-western to south-east

- Monitoring of $\mathrm{w} / \mathrm{r}$ and gas steam ratio indicates that there is a potensial decline in the reserved fluid (water saturation) in the reservoir from $35 \%$ at the beginning (1979) become $28.4 \%$ in present

- The results of monitoring evaluation qualitatively confirm that there is interconnection between KMJ 15 and production with water recovery of around $13.5 \%$, which is equivalent to $6.35 \times 10^{5}$ tons of water. 


\section{REFERENCES}

1. AXELSSON, G., Tracer Test in Geothermal Systems, IAEA INT/0/060 Meeting, Nairobi, Kenya (2002).

2. CEllati, R., CAPPETTI, G., CAlORE, C., GRAASI, S., and., D'AMORE, F., Geothermics, 20 ( 3), 119-131 (1991).

3. D'AMORE, F., and., TRUESDELLl, A.H., Proc. World Geothermal Congress, 1927 - 1931 (1995).

4. GRANT, M.A., Geothermics, 8, 21-30 (1979).

5. GUNDERSON, R.P., : "Distribution of Oxygen Isotopes and Non Condensable Gas in Steam at the Geyser", Characterization of Reservoir, Unocal Geothermal Division, Santa Rosa, California (1991).

6. ROBERT, D., Subsurface Study on the Optimization of the Development of the Kamojang Geothermal Field, BEICIP/ GEOSERVICE Report for Pertamina (1988).

7. SATYAJIT, D., et al., Kamojang Steam Field Managemant, Proceeding Workshop Sehari Geothermal Steam Field Management, Pertamina Area Panasbumi EP Kamojang, November. (1999). 